DOI: https://dx.doi.org/10.4314/gjedr.v18i2.4

GLOBAL JOURNAL OF EDUCATIONAL RESEARCH VOL 18, 2019: 81-89

COPYRIGHT@ BACHUDO SCIENCE CO. LTD PRINTED IN NIGERIA. ISSN 1596-6224

www.globaljournalseries.com; Info@globaljournalseries.com

\title{
RELIGIOUS VALUE ORIENTATION AND SELF-EFFICACY AMONG SECONDARY SCHOOL STUDENTS IN CROSS RIVER STATE, NIGERIA.
}

ACHI NDIFON BEKOMSON AND NTAMU, BLESSING AGBO

(Received 6, May 2019; Revision Accepted 6, June 2019)

\begin{abstract}
The purpose of the study was to find out if religious value orientation has any influence on self- efficacy with regards to social self efficacy, academic self efficacy, language self efficacy and moral self efficacy. Ex -post facto design was adopted for the study. The sample consisted of 1,543 students randomly selected from 47 public schools in Cross River State. A self designed questionnaire titled Religious Value Orientation and Self-Efficacy Questionnaire (RVOASEQ) was used to collect data for the study. The face validity of the instrument was determined by four research experts in Educational Psychology and measurement and evaluation, while the reliability of the instrument was determined using Cronbach Alpha reliability method. The data collected from 1,529 subjects were analysed using One Way Analysis of Variance statistical tool, tested at . 05 level of significance. The result of the analyses revealed that religious value orientation significantly influence all the dimensions of students' self-efficacy except social self-efficacy. Based on the findings of this study, it was recommended that teachers should encourage students to belong to social groups in school, to enable them develop skills that will help them build their social competence and also engage students in religious discussions and activities that will help them build up a positive religious standing that will guide their activities.

\section{INTRODUCTION}

Self-efficacy is defined as peoples' beliefs about their capabilities to produce designated levels of performance that exert influence over events that affect their lives (Pajares, 2002). The way people think, feel, react to events and motivate themselves is determined by their self-efficacy beliefs. Students who have high assurances in their capabilities see difficult task as challenges that must be tackled rather than as threats to be avoided. Students with high self-efficacy have deep interest for activities, they set goals for themselves and are committed towards achieving such goals and resist failures and setbacks.

Unfortunately, that is not the case for most secondary school students today. The researchers have discovered from personal observation and interaction with students that most students find it difficult to recover their sense of efficacy after failing, they avoid difficult assignments which they see as personal threats, they are poorly committed to set gaols, they dwell on their personal shortcomings, and give up easily when faced with difficult assignments which makes them easily prone to stress and depression.

This trend got the researchers worried that despite all that parents, teachers, school administrators and the government have put in
\end{abstract}

Achi Ndifon Bekomson, Department of Educational Foundations, University of Calabar, Nigeria. Ntamu, Blessing Agbo, Department of Educational Foundations, University of Calabar, Nigeria. 
place, like debate, quiz, essay writing, cultural and football competitions to boost students selfefficacy, students still show little or no improvement. It is based on the aforementioned that the researchers sought to find out if religious value orientation has any influence on selfefficacy of students.

Researchers believe that religion and spirituality are basic components of life satisfaction. They believe that religion has a positive effect on the quality of life, sustainable life, positive performance, physical and mental stability that quickens performance, and brings about life satisfaction (Lukes, 2006, Saybold and Hills, 2001, Bakshshpour-Roudsari, 2008). This brings us closer to the relationship between religious value orientation and self-efficacy as prescribed by Marashia, and Esmaili,

(2012).

Bidgeloo and Bozorgi (2016), carried out a study to investigate the relationship between religious attitude and self-efficacy with a sample of 253 high school teachers in Mahshaahr city in Iran. The researchers adopted the Pearson's correlation coefficient for data analysis. The result showed a significant positive relationship between religious attitude and self-efficacy. The result further showed that religious attitude and self-efficacy predict the social life of individuals. This means that one's social life regarding their family, job and other areas of life could be predicted by religious attitude and self-efficacy. Furthermore, individual welfare is affected by the self-awareness, optimism, and spiritualism. This means that, the more conscious individuals are regarding their spiritual and social lives, the higher their level of self-efficacy (Marashia \& Esmaili, 2012).

Lawler-Row and Elliot (2009) in an investigative study on the role of religion and spirituality on the well-being of old people found religion and spirituality to be significant predictors of wellbeing of old people. However, Okulicz-Kozaryu, (2009) in a study showed a significant relationship between religious dimensions and life satisfaction. It is the satisfaction individuals get about what they do that boost their selfefficacy. Gholami (2009) opined that peoples' belief play a significant role in their lives and the way they behave. Their beliefs according to this researcher help direct their psychological life and their decision making ability in diverse situations. Gholami (2009) maintained that peoples' performance whether weak, moderate or strong depends on changes in their beliefs on self- efficacy. He sees self-efficacy as one of the basic components of peoples' success/achievement.

Furthermore, Malik, Gupta, and Braich (2012), argued that there is a relationship between religiosity, spiritual beliefs and self-efficacy. According to them, spirituality can play an important role as a coping strategy, solve problems and ease off stress in our day to day life. They maintained that self-efficacy is high in people who are religiously inclined, as they believe that their faith in God gives them confidence and promote efficiency. Abolghasemi and Javanmiri, (2012) reiterated that religion is an aspect that affects self-efficacy because of its powerful effect on the emotional, psychological and behavioural problems of people.

Similarly, Barakoska (2014) is of the view that value orientation serve as a general indicator of the orientation of spiritual development. He pointed out that, the perspectives of adolescents development in the society depends on-their religious value orientation as it plays an important role in the social life of individuals. This implies that people who are oriented toward religious values, with regard to their close relationship with God, get more satisfied with their lives. Moslehi and Ahmadi (2013), pointed out that religious attitude and beliefs affect people's interpretation of events, their thoughts, and gives them satisfaction in life.

In another development, Beque (2002) observed that alcoholics who are religiously oriented are protected against recurrence of the syndrome because of the self-efficacy acquired. This means that attending religious gathering positively affect their sense of moral well-being and self-efficacy. It is believed that there is a strong relationship between religions commitment and well-being, including happiness, life satisfaction, positive effects, optimism and hope (Baetz, 2002). Relatedly, religious orientation including beliefs in God, help individuals to overcome vulnerability, low self-esteem, and helplessness when at the face of challenge, and promote self-efficacy. This implies that religious orientation enable individuals to cope with school related stressors, interpersonal demands and attainment of social interaction (Nafagi and Fouladchange, 2017). Bagheri (2013) is of the view that self-efficacy belief determines the level of attention people give to a task, resist problems and show willingness to face challenging situations.

In the same vein, Lotfizadeh \& Beyrami (2013), maintained that self-efficacy plays an important role in knowledge acquisition, application, and 
development of academic skills. In other words, students who believe they can succeed academically, show more willingness and perseverance in fulfilling educational duties, and have more confidence in their abilities. On the other hand, Fritzche and Parish (2005) describe people with poor self-efficacy as those who lack control over life's event, and lacks the capability to withstand challenges, are helpless, and lose hope easily. Which means that perception of selfefficacy can help individuals, have a positive perspective on objectives, task and challenges at hand (Cain, Bardon-cone, Abramson, Vohs, and Joiner, 2008). Fadakari (2011) pointed out that individuals oriented toward religiosity have efficacy since religiosity serve as a way of relaxing and discarding conflicting thoughts.

Obviously, religious values are important for selfefficacy motivation. Mohd, Kirang-Kamaruddin, Zainuddin and Ghazali (2014) carried out a study to determine the mediating role of self-efficacy on the relationship between religious values and entrepreneurial orientation. The sample consisted of 162 small scale Malay SMEs in manufacturing industry, who have been in business between five to ten years, from the whole states of Malaysia and the results of the study revealed that self-efficacy of Malay owner managers acted as full mediating role in the relationship between religious values and entrepreneurial orientation. The results further revealed that individuals who are courageous, honest and disciplined, have high self-efficacy to be innovative and entrepreneurial. All the hypotheses examined in this study, supports the assumption that selfefficacy, relates to religious values and entrepreneurial orientation.

Farshad, Farrahbakhsh and Salmabadi (2015) carried out a study on simple and multiple correlation between religious belief, life expectancy and self-efficacy of students using students in Shiraz with a sample of 243 individuals through a stratified random sampling technique. The result of their study indicated that students predict their self-efficacy. Accordingly, they stated that people with religious beliefs enjoy higher self-efficacy. Milson (2002) in the same vein conducted a correlation study on teacher efficacy and character education using a sample of 767 elementary teachers in a large mid-western sub-urban school district to ascertain the efficacy beliefs of practicing elementary level teachers. The results suggest that teachers who had degrees from private religiously affiliated universities had a greater sense of efficacy for character development. This means that religious value orientation influences self-efficacy with regard to character development. The findings suggest that programs in private, religiously affiliated universities might serve as a model for character education.

Onutobor (2010) in his study on life satisfaction, self-efficacy and religious faith in stroke patients living in Kuwait assessed the quantitative relationship between self-efficacy, life satisfaction and religious faith using a semi structured interview, found out that religious faith was not related to self-efficacy. The study failed to show any significant relationship between religious value orientations which is referred in the study as religious faith and self-efficacy in female stroke patients. In contrast with the study of Onutobor (2010), Syeda and Ali, (2015) which explored the interrelationship of religious faith and self-efficacy using 222 regular students comprising of 110 men and 112 women, between the ages of 18 and 26, using a descriptive statistics, found a significant and positive relationship between religious beliefs and selfefficacy. Kapur (1986) stressed that religious value orientation relating to Karma and redemption of sin, sexual division of labour are regarded as guide to behaviour, and a positive orientation toward such values help children to stand up to what they belief without fear. Poonam, (2006), postulated that students who are oriented toward religious and moral values tend to be inclined to art subjects. Moghadam, Tojari and Khodayari, (2015) in a study of relationship practice, religious beliefs and selfefficacy with competitive anxiety, determined the relationship between religious beliefs and selfefficacy. The sample for their study consisted of 327 Judoka people, a self-efficacy and beliefs questionnaire was employed to get responses from the subjects and data were analyzed, using descriptive, Pearson correlation and regression statistics. The result showed that there is a significant relationship between religious beliefs and self-efficacy. Richard \& Bergin (1999), Perzgi (2009), contradicted Moghadams findings by stating that the fact that religious people feel that God loves them and advocate their causes, give them a higher self-efficacy than other groups.

In a study conducted by Cheraghi and Tajar (2015), to examine the relationship between religious orientation and psychological endurance, commitment, control and defiance using 150 students at the University branches of Payam Noor in Kermanshah province as sample. 
The findings of their study revealed that between religious orientation and factors of psychological endurance from both the inner and the outer dimensions, there is a significant and positive relationship. Brown, Ndubuisi and Gary (1990), studied religiosity and psychological distress among blacks, using a probability based sample of 451 urban black Americans and found that religiosity was associated with psychological distress, based on one's orientation.

King and Furrow (2001) in a study to examine the association between religious attendance, social capital and moral outcomes, using an ethnically-diverse sample of high school students. Using a questionnaire format to examine the relationship, it was gathered that those who were religiously oriented were found to be more inclined to social capital with respect to social interaction.

In a study carried out by Melissa (2013) on Ethical reasoning of accounting students: Does religiosity matter? The goal of the study was to find out if levels of religiosity and attendance at school related to the ethical reasoning skills of accounting students. The sample of the study consisted of 170 undergraduates and non-accounting students of three religiously affiliated college and secular college. A questionnaire was used to collect data, while regression analysis was used to analyze the data. The result of the study showed that both higher levels of intrinsic religiously and attendance at a religiously affiliated college results in academic self-efficacy with regard to ethical reasoning skills among accounting students. In a similar study carried out by Rawwas, et al., (2006) to examine the relationship of academic dishonesty and religiosity, in respect to the personal beliefs, values, age and gender, opportunism on the behaviour of students of two universities in Japan, it was revealed that students of both schools exhibited academic dishonesty when given the opportunity. A further analysis revealed that their religious value orientation did not influence their decision to involve in dishonest acts but led to fear after the act. Conroy and Emerson (2004) found a significant relationship between religious moral value orientation and negative behaviours of students.

Relatedly, Soontornpathai, Ravinder and Sittichai (2014) in a study on relationship between lifestyle values and achievement goal orientation among vocational students in Thailand, with a total of 1670 students made up of $38.5 \%$ males and $61.5 \%$ female as sample, using multiple regression analyses recorded a significantly positive relationship between value orientation and performance goal in respect to self-determination. Mara, Alan, Daniel, and Lynn (2010) conducted a study to investigate if religions faith improves test performance among college students who responded to a self-efficacy scale. The result revealed that religious value orientation did not significantly influence selfefficacy in terms of logical reasoning.

Consequently, Regnerus and Glen (2001) in a study on track in school: Religious influences in high and low risk setting, used data from the National Longitudinal study of Adolescent Health in Carolina, found that children from low income families who attended church regularly recorded high level of academic progress than their counterparts from high income families. In a similar study, by Regnerus (2000) on shaping schooling success: Religious socialization and educational outcomes in metropolitan public schools, using public schools in metropolitan U.S area, found out that religions value orientation significantly affected students' educational expectations. He discovered that students who were more religiously inclined scored higher on standardized Mathematics and reading tests. This therefore means that religious value orientation has a significant influence on academic self-efficacy.

In a study by Fabio, Arnaldo, Luca, Gampaolo, Lambros and Martin (2017) on moral attitudes and cheating behaviours, using a total sample of 314 tennis players, $76.75 \%$ males

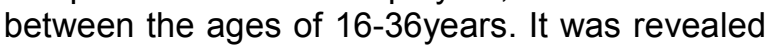
that athletes who were morally oriented had antisocial attitudes which directly predicted cheating behaviour in match play. The implication of this is that moral value orientation influences the moral self-efficacy of athletes.

Gian and Paatrizia (2007) carried out a study to examine a conceptual model in which efficacy beliefs and transcendence values like benevolence and universalism promote prosocial behaviour, using a large sample from Italian population made up of six age groups as study sample and a questionnaire to collect data. It was discovered that self-transcendence values affect pro-social behaviour directly or indirectly through self-efficacy beliefs in managing interpersonal relationships. 
PURPOSE OF THE STUDY:

The purpose of the study is to find out if religious value orientation has any influence on self efficacy.

Significance of the study:

The study has added to existing body of knowledge by establishing that religious value orientation has the potency of improving students' self-efficacy. The study is therefore of benefit to parents, students, teachers, school psychologist, guidance counsellors and school administrators. It is hoped that the findings of this study will help them understand the importance of religious value orientation in boosting self efficacy.

\section{METHODOLOGY}

The research design for this study was the expost facto design. The design is aimed at investigating cause and effect relationship between two variables by identifying consequences that exist and collecting data for possible causal factors. In this study, the design is appropriate because data collected were used to compare the extent of influence of value orientation on self-efficacy and the extent to which interest in schooling can influence selfefficacy of students. Ex-post facto design is suitable also because it is impossible for the researcher to create a situation or event that will warrant the students display their various levels of self-efficacy at the time of the investigation.

The research area for the study is Cross River State.

The population of the study consists of all the 38,514 Senior Secondary I and II Students $(18,697$ males and 19,817 females) spread across the 246 government secondary schools in Cross River State under the State Secondary Education Board (S.S.E.B) during the 2016/2017 academic year. A breakdown of the population shows that there are 1,641 students in Akamkpa, 656 students in Akpabuyo, 276 students in Bakassi, 3,705 students in Calabar South, 1,434 students in Biase, 5,815 students in Calabar Municipality, 1,095 students in Odukpani, 2,457 students in Obudu, 2,675 students in Yala, 1,397 in Bekwarra

Stratified random sampling technique was used for the study. The schools in the area were first stratified based on LGA and the researchers randomly selected $20 \%$ of the schools in each of the LGAs through hat and draw method (balloting).
The sample used for this study consist of 1,529 students (663 males and 866 females) randomly selected from 47 public secondary schools in Cross River State. A total of 802 students were selected from SS I classes and 741 students from SS II classes.

The instrument used for data collection is a questionnaire titled Value Orientation and Selfefficacy Questionnaire (VOSEQ). The questionnaire consists of three sections. Section A elicited from the respondent demographic information, such as age and gender. Section B is made up of six items designed to measure religious value orientation and Section $C$ is designed with 24 items to measure the dependent variable, with four sub sections and six items to measure each sub variable of selfefficacy such as social self-efficacy, academic self-efficacy, language self-efficacy and moral self-efficacy. The scale is a four point Likert type. Four experts validated the instruments.

To determine the reliability of the research instrument, a trial testing was done using fifty (50) students from three (3) secondary schools who did not take part in the actual study. Part B of the scale was organized with 6 items to measure religious value orientation. The scale using Cronbach alpha approach yielded coefficient of .79 for religious value orientation. Part $\mathrm{C}$ of the scale is organized in five sub-scale (social self-efficacy, academic self-efficacy, language self-efficacy, moral self-efficacy and overall self-efficacy). Each sub-scale using Cronbach alpha approach yielded coefficient ranging from .75 for academic self-efficacy to .84 for moral self-efficacy.

The researchers personally administered copies of the questionnaire to the 1,543 subjects with the help of two research assistants and some class teachers.

It was observed that out of the initial sample of 1,543 selected for the study, only 1529 successfully completed the instrument used for the data analyses while 14 copies of the instrument which were not properly filled were discarded. One-way Analysis of Variance was used in testing the null hypotheses at .05 level of significance. The procedures used for the data analyses are presented as follows:

\section{HYPOTHESIS}

Religious value orientation does not significantly influence students' self-efficacy.

The independent variable in this hypothesis was religious value orientation categorized into three 
levels (low, moderate and high), while the dependent variable was self-efficacy with four sub-components, namely, social self-efficacy, academic self-efficacy, language self-efficacy, moral self-efficacy and overall self-efficacy. The One-way Analysis of Variance was used in testing this hypothesis, and the results of the analyses were as presented in Table 1 . The result as presented in Table 1 show that the $F$ ratios of $1.420,21.910,61.104,27.142$ and 39.375 produced for social self-efficacy, academic self-efficacy, language self-efficacy, moral self-efficacy and the overall self-efficacy respectively are each significant at 2 and 1526 degrees of freedom and .05 level of significance.

TABLE 1

One-way Analysis of Variance of the influence of religious value orientation on self-efficacy

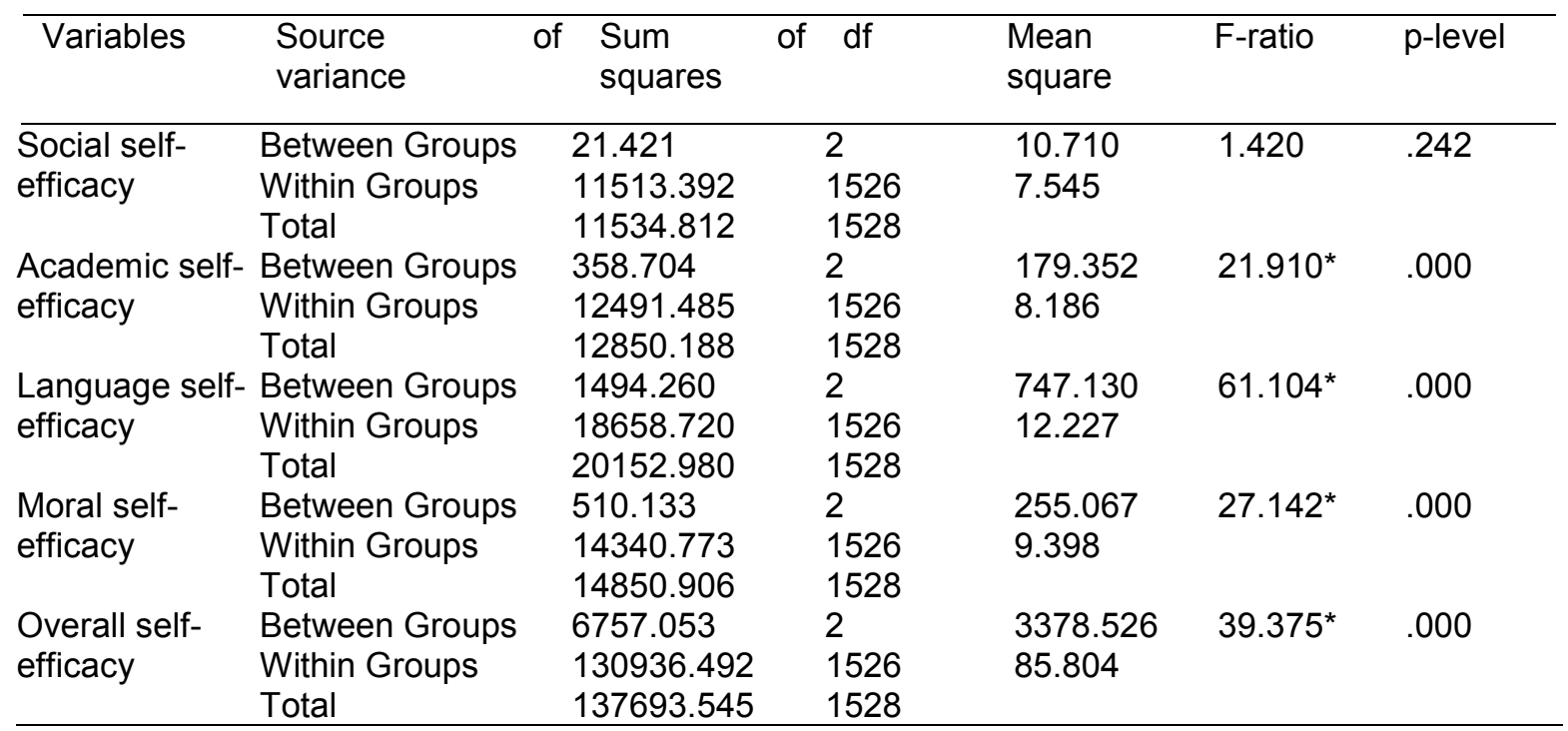

*Significant at .05 alpha level; $p<.05$.

By implication, the null hypothesis that religious value orientation does not significantly influence students' self-efficacy was rejected for all the various dimensions and overall self-efficacy except for social self-efficacy. These results imply that, religious value orientation significantly influence students' self-efficacy except for social self-efficacy.

Given the significant F-ratios, a post hoc analysis was conducted using the Fishers' Least Significant Difference (LSD) multiple comparison test to check for the source of the difference. The results are presented in Table 2.

An examination of the results in Table 2 showed that the subjects who had low level of religious value orientation had significant lower mean in academic self-efficacy when compared with those who had moderate level of religious value orientation (MD=-.18; $\mathrm{p}>.05$ ) but they had a significant lower mean in academic self-efficacy when compared with those who had high level of religious value orientation $(M D=-1.31 ; p<.05)$. Other pair wise comparison between the subjects who have moderate and high level of religious value orientation, produced a mean difference that was not statistically significant $(M D=-1.13$; $p>.05)$.

Furthermore, for language self-efficacy, the results show that the subjects who had low level of religious value orientation had a significant lower mean in language self-efficacy when compared with those who had moderate level of religious value orientation $(M D=-1.17 ; p<.05)$, and they also had a significant lower mean in language self-efficacy when compared with those that have high level of religious value orientation $(\mathrm{MD}=-3.06$; $\mathrm{p}<.05)$; Other pair wise comparison showed that the subjects who have moderate level of religious value orientation had a significant lower mean in language self-efficacy when compared with those who had high level of religious value orientation $(\mathrm{MD}=-1.89 ; \mathrm{p}<.05)$. 


\section{TABLE 2}

Fisher's Least Significance Difference (LSD) multi-comparison test analysis of the influence of religious value orientation on self-efficacy

\begin{tabular}{|c|c|c|c|c|}
\hline Dependent Variable & $\begin{array}{l}\text { (I) Religious value } \\
\text { orientation }\end{array}$ & $\begin{array}{l}\text { (J) Religious value } \\
\text { orientation }\end{array}$ & $\begin{array}{l}\text { Mean } \\
\text { Difference (I-J) }\end{array}$ & p-level \\
\hline \multirow{6}{*}{ Academic self-efficacy } & Low & Moderate & -.18 & .355 \\
\hline & & High & $-1.31^{*}$ & .000 \\
\hline & Moderate & Low & .18 & .355 \\
\hline & & High & $-1.13^{*}$ & .000 \\
\hline & High & Low & $1.31^{*}$ & .000 \\
\hline & & Moderate & $1.13^{*}$ & .000 \\
\hline \multirow[t]{6}{*}{ Language self-efficacy } & Low & Moderate & $-1.17^{*}$ & .000 \\
\hline & & High & $-3.06^{*}$ & .000 \\
\hline & Moderate & Low & $1.17^{*}$ & .000 \\
\hline & & High & $-1.89^{*}$ & .000 \\
\hline & High & Low & $3.06^{*}$ & .000 \\
\hline & & Moderate & $1.89^{*}$ & .000 \\
\hline \multirow[t]{6}{*}{ Moral self-efficacy } & Low & Moderate & $-.74^{*}$ & .000 \\
\hline & & High & $-1.80^{*}$ & .000 \\
\hline & Moderate & Low & $.74^{\pi}$ & .000 \\
\hline & & High & $-1.06^{*}$ & .000 \\
\hline & High & Low & $1.80^{*}$ & .000 \\
\hline & & Moderate & $1.06^{*}$ & .000 \\
\hline \multirow[t]{6}{*}{ Overall self-efficacy } & Low & Moderate & $-2.39^{x}$ & .000 \\
\hline & & High & $-6.47^{*}$ & .000 \\
\hline & Moderate & Low & $2.39^{*}$ & .000 \\
\hline & & High & $-4.08^{\pi}$ & .000 \\
\hline & High & Low & $6.47^{\pi}$ & .000 \\
\hline & & Moderate & $4.08^{x}$ & .000 \\
\hline
\end{tabular}

*The mean difference is significant at the .05 level.

Concerning moral self-efficacy, the results show that the subjects who had low level of religious value orientation, had significant lower mean on moral self-efficacy when compared with those who had moderate level of religious value orientation (MD=-.74; $\mathrm{p}<.05)$, and they also had a significant lower mean when compared with those who had high level of religious value orientation $(\mathrm{MD}=-1.80 ; \mathrm{p}<.05)$. Other pair wise comparison show that the subjects who had moderate level of religious value orientation had a significant lower mean on moral self-efficacy when compared with those who had high level of religious value orientation (MD=-1.06; $p<.05)$.

Finally, for overall self-efficacy, the results show that the subjects who had low level of religious value orientation had a significant lower mean when compared with those who had moderate level of religious value orientation ( $M D=-2.39$; $\mathrm{p}<.05$ ), and they also had a significant lower mean when compared with those who had high level of religious value orientation $(M D=-6.47$; $\mathrm{p}<.05$ ). Other pair wise comparison showed that the subjects who had moderate level of religious value orientation had a significant lower mean in the overall self-efficacy when compared with those who had high level of religious value orientation $(\mathrm{MD}=-4.08 ; \mathrm{p}<.05)$.

\section{CONCLUSION AND RECOMMENDATIONS:}

It was concluded that religious value orientation has no significant influence on social self-efficacy but has an influence on academic, language and moral self-efficacy respectively.

Based on the findings of this study, the following recommendations were made:

1. Teachers should try as much as possible to encourage group activities that will help students develop interest in working together with others to improve their social competence

2. Parents and teachers should engage students in religious discussions and activities 
that will help them build up a positive religious standing and guide their activities.

\section{REFERENCES}

Abolghasemi, A. and Javanmuri, I., 2012. Social desirability, mental health and self- efficacy in predicting academic achievement of female students. Journal of School Psychology, 1(2), 6-20.

Baetz, M., Larson, P. B., Marcoux, G., Bowen, R. and Griffin, R., 2002. Canadian psychiatric impatient religious commitment: An Association with Mental Health. Can J. Psychiatry, 47(2), 159-66.

Bagheri, N., 2013. The relationship between the life satisfactions of elderly people in Sari in 2012. Journal of Mazandaran University of Medical Sciences, 101, 38-47.

Bakhshipour-Roudasri, A., 2008. Relationship between the life satisfaction, problem solving style and religions attitude with mental health. Journal of Psychology, University of Tabriz, 9, 8-26.

Beque, I., 2002. Beliefs in justice and faith in people: Just world, religiosity and interpersonal trust. Personality and Individual Differences, 32(3), 375-82.

Bigdeloo, M., and Bozorgi, Z. A., 2016. Relationship between the religious attitude, self-efficacy, and life satisfaction in high school teachers of Mashahr City. Journal of International Education Studies, 9(9), 5866.

Cain, A., S., Bardone-Cone, A. M., Abramson, L. Y., Vohs, K. D. and Joiner, I. E., 2008. Refining the relationship of perfectionism, self-efficacy and stress to dieting and binge eating: Examining the appearance, inter-personal and academic domains. International Journal of Eating Discord, 41(8), 713-721.

Fadakar, D. F., 2011. Determining the predictability of self-esteem, self-efficacy, self-discrimination and intrinsic and extrinsic religiously through parenting practices.

Farshadi, M. R., Farrahbaklish, K. and Salmabadi, M., 2015. Simple and multiple correlation between religious belief life expectancy and self-efficacy of students. International Journal of School Health, 2(3), 1-5.
Fritzsche, B. A. and Parrish, T. J., 2005. Theories and research on job satisfaction. In S. D. Brown, and R. W. Lent (eds), Career development and counselling: Putting theory and research to work (pp. 180202). Wile, Hoboken, NJ.

Gholami, M., 2009. Study of the relation between collective efficacy beliefs and self- efficacy beliefs with job satisfaction of male teachers of Qom high schools. Master's Thesis in General Psychology, University of Tehran).

Kapur, M., 1986. The moral education of primary school children: A sociological perspective. Doctoral dissertation, Sociology, Delhi University.

Lawler-Row, K. A., and Elliot, J., 2009. The role of religious activities and spirituality in the health and well-being of older adults. Journal of Health Psychology, 14(1), 4352.

Lukes, O., 2006. Testing freedom: Happiness religion and economic transition. Journal of Economic Behaviour and Organization, 59, 173-194.

Lotfizadel, A. M. and Beyrami, M., 2013. Comprehensive study of public health and self-efficacy of students with low religious beliefs fabrics.

Malik, S., Gupta, M., and Brauch, J., 2012. Current scenario of malaria vaccine. International Journal of Basic and Clinical Pharmacology, 1(2), 60-66.

Marashian, F., and Esmaili, E., 2012. The relationship between spiritual adaptation and life satisfaction with mental health of the students of Islamic Azad University of Ahuaz. Journal of New Findings in Psychology, 24, 85-98.

Melissa Gaa, M. A., 2008. Moral development, counselling, self-efficacy, and counsellors-in-training sexual orientation counselling competencies. A Doctoral dissertation submitted to the Graduate Faculty of the Texas Technology University.

Moslehi, J. and Ahmadi, M. R., 2013. The role of religious life in marital satisfaction. Journal for the Psychology of Religion, 2, 75-90.

Mohd, R., Kirang, K., Kamaruddin, B. H., Zainuddin, A. and Ghazali, M. C., 2014. The mediatory effect of selfefficacy on the relationship between religious 
values and entrepreneurial orientations: $A$ case of Malay Owner Managers of SMEs in Manufacturing Industry. Science Direct: Procedia Social and Behavioural Sciences, 130, 96-104.

Najafi, M. and Fouladchang, M., 2017. The relationship between self-efficacy and mental health of high school students. Scientific-Research Journal of Shahed University, 14(12), 34-45.

Olulicz-Kozaryn, A., 2009. Religiosity and life satisfaction. (A multinational investigation across nations). Institute for Quantitative Social Science, Harvard University.

Pajares, F., 2003. Self-efficacy beliefs, motivation, and acknowledge in writing: A review of the literature. Reading and Writing Quarterly, 19, 139-158.

Seybold, K. S., and Hills, P. C., 2001. The role of religion and spirituality in mental and physical health. Journal of Current Directors in Psychological Science, 16, 21-24.

Conroy, S.J, and Emerson, T. L. N., 2004. Business ethics and religion: Religiosity as a predictor of ethical awareness among students. Journal of Business Ethics. 50, (4), 383-396.

Soontornpanthai, C, Ravinder, K, and Sittichai, K. Relationship between lifestyle values and achievement goal orientation among vocational students in Thailand. 36-47. Retrieved from https://doi.org on 19-122018.

Mara, S. A, Allan, K. G, Danniel, H.M, William, J. J, and Lynn, E. M., 2012. Does religious faith improve test performance? North American Journal of Psychology. 14, (1). Retrieved from https://www.questia.com

Regnerus, M. D and Glen, H. E., 2003. Staying on track in school: Religious influences in high and low risk settings. Journal for The Scientific Study of Religion. 42, (4), 633-649.

Barakoska, A. and Jovkoska, A., 2014. The role of education in formation of values and value orientations among adolescents. International Journal of Cognitive Research

$\begin{array}{lrr}\text { in Science, } & \text { Engineering } & \text { and } \\ \text { Education. 2. } 2 . & \text { Retrieved } & \text { from } \\ \text { https://www.google.com. } & & \end{array}$

Howsepian, B. A, and Merluzzi, T. V., 2009. Religious beliefs, social support, self-efficacy and adjustment to cancer. Psychooncology: 18,(10),1069-1079.

Cheraghi, K and Tajar, J., 2015. The study of the relationship between religious orientation and psychological endurance (commitment, control and defiance) in male and female students. Indian Journal of Fundamental and Applied Life Sciences. 5(52),518-522 Retrieved from www.cibtech.org on 1-10 2018.

King P. E. and Furrow J. L., 2004. Religion as a resource for positive youth development: Religion, social capital, and moral outcomes. Developmental Psychology. 10,(5),703-713.

Rawwas, M. Y. A, Swaidan, Z. and Alkhalib, J., 2006. Does religion matter? A comparison study of the ethical beliefs of marketing students of religious and secular university in Japan. Journal of Business ethics. 65 , (1),69-86.

Fabio, L, Arnaldo, Z, Luca, M, Giamnpaoo, N, Lambros, L, Martin, H., 2017. Moral attitudes predict cheating and gamesmanship behaviours among competitive tennis players. Frontiers in Psychology. 8, 517. Retrieved from https://shura.shu.ac.ukon 7-3 -2018.

Milson, A. J. and Mehlig, L. M., 2002. Elementary school teachers' sense of efficacy for character education. Journal of Educational Resaerch. 96,(1),47-53.

Omu, O., 2010. Life satisfaction, self-efficacy and religion faith in stroke patients living in Kuwait. Retrieved from https://core.ac.uk on 7-11-2018.

Ali, A. Z. and Shah, S. S., 2015. Religious faith flourishing and self- efficacy in young adults: A correlation study. Retrieved from https://www.researchgatenet.net on $157-2018$ 